\title{
MORPHOLOGICAL AND MOLECULAR DIFFERENTIATION OF THE PECTINASE PRODUCING FUNGI PENICILLIUM EXPANSUM AND PENICILLIUM GRISEOROSEUM
}

\author{
Patrícia Gomes Cardoso; Marisa Vieira de Queiroz; Olinto Liparini Pereira; Elza Fernandes de Araújo* \\ Departamento de Microbiologia/BIOAGRO, Universidade Federal de Viçosa, Viçosa-MG, Brazil \\ Submitted: May 15, 2006; Returned to authors for corrections: August 28, 2006; Approved: January 18, 2007.
}

\begin{abstract}
Two species from the genus Penicillium, Penicillium expansum and P. griseoroseum (Brasilian isolates) were characterized morphologic and molecularlly. Morphological variability was detected among isolates in regard to colony morphology and to conidia coloration. The molecular characterization was based on the RAPD markers, telomeric fingerprinting and ITS sequencing. A total of 78 RAPD primers were used and 8 presented differences in band patterns with 54\% of the amplified polymorphic fragments. The monomorphic fragments of $600 \mathrm{bp}$ (P. expansum) and $594 \mathrm{bp}($. griseoroseum) were amplified. The only internal transcribed spacer region variation detected between the two species was the additional six initial nucleotides. The analysis by telomeric fingerprinting showed polymorphism between both species and the chromosome minimal numbers estimated were three. The polymorphism observed in the organization of the subtelomeric region in the genome of two Penicillium species within the high homogeneous Penicillium subgenus is for the first time reported and perhaps can be employed in future phylogenetic studies.
\end{abstract}

Key words: Ribossomal DNA, Internal Transcribed Spacer, Subtelomeric Region, Penicillium spp.

\section{INTRODUCTION}

The genus Penicillium is worldwide known for production of secondary metabolites and extracellular enzymes of commercial value, including the pectinases, utilized in fruit juice industry during the stage of pulp maceration, juice liquefaction or depectinization (19). Most Penicillium species are considered ubiquitous, opportunistic saprophytes. Nutritionally, they are supremely undemanding being able to grow in almost any environment with a sprinkling of mineral salts, any but the most complex forms of organic carbon, and a wide range of physical-chemical environments, $\mathrm{a}_{\mathrm{w}}$, temperature, $\mathrm{pH}$ and redox potential. The taxonomy of this genus is hard as its classification is based mainly on conidiophore and conidia structure, although the colony diameter after incubation under standardized conditions has greater importance for classification (31). The genus Penicillium is subdivided in four subgenera (Aspergilloides, Penicillium, Biverticillium and
Furcatum) determined by the number of branch points between phialide and stipe, down the main axis of the penicillus and others characters, like ratio of metula length to phialide, length and colony diameter on $\mathrm{G} 25 \mathrm{~N}$, when the number of branch points is the same (31).

Two species from the genus Penicillium, $P$. expansum and $P$. griseoroseum have been selected in our laboratory and they were shown to be excellent pectinase producers (4). These species have been extensively studied physiologically, showing clear differences in their answers to the influence of inoculum age and concentration, as the effect of some cultural conditions (growth period, substrate concentration and different carbon sources) on the production of pectin lyase (PL) and polygalacturonase (PG). The P. griseoroseum PL activity was highest with 9-day-old spore, $5 \times 10^{4}$ spores $/ \mathrm{mL}$ after $48 \mathrm{~h}$ of growth and the P. expansum PL activity with 5-day-old spore, $10^{6}$ spores $/ \mathrm{mL}$ after $72 \mathrm{~h}$ of growth $(1-3,10,11,26,27)$. Several genetic studies have been carried out in our laboratory in order to isolate strains with enhanced

*Corresponding Author. Mailing address: UFV - BIAGRO - Dep. de Microbiologia 36570-000. Viçosa, MG - Brasil. Tel.: (31) 3899-2553 ou (31) 3899-2573. E-mail: ezfa@ufv.br 
pectinolytic enzyme activities. Different methodologies which have been used to achieve these goals include protoplast production and regeneration, mutant isolation and characterization, protoplast transformation and isolation and characterization of genes coding pectinolytic enzyme in $P$. griseoroseum and P. expansum. $(5,9,12,13,16,21,33,34-36,38,41)$. Incompatibility was observed between these two species for the formation of heterokaryons and diploids when conidia were mixed (41). When the parasexual cycle of $P$. expansum was analyzed, it was noted that diploids were rather unstable and that recombinant sectors could easily be isolated (21). Nevertheless, was observed different results with $P$. griseoroseum, in which the parasexual cycle was not obtained spontaneously, and the diploids isolated by protoplast fusion were stable and produced few discrete haploid sectors even when placed in complete medium supplemented with benomil (38). High identity in amino acid sequence and similar global organization in PL and PG genes from P. expansum and P. griseoroseum was showed (5,12,34-36). Penicillium expansum PLE1 shares $100 \%$ amino acids identity with PLG1 from P. griseoroseum and the organization of PL genes showed same hybridization pattern what suggests that PL genes have a similar global organization in the genome segment in which they are found. Some doubts emerged from the genetics studies with respect to the basic differences that are required for strains to be considered different species.

The objective of this study was to analyze the differentiation of the pectinase-producing fungi Penicillium expansum and Penicillium griseoroseum employing both morphological and molecular methods. The use of molecular techniques based on the random amplified polymorphic DNA (RAPD) and sequencing of the internal transcribed spacer (ITS) region of the ribosomal DNA (rDNA) have been useful for the identification and classification taxonomy of filamentous fungi.

\section{MATERIALS AND METHODS}

\section{Strains and growth conditions}

Penicillium expansum and $P$. griseoroseum isolates were obtained from forest tree seeds collected at Universidade Federal de Viçosa, Minas Gerais, Brazil. The isolate of Penicillium griseoroseum was deposited at Fundação Tropical de Tecnologia e Pesquisas André Toselo (Campinas, São Paulo, Brazil), under the code register CCT 6241, and the P. expansum isolate was deposited at VIC Herbarium (Viçosa, Minas Gerais, Brazil), under the code register VIC 28728. Cultures were also kept in incubation on agar $/ \mathrm{H}_{2} \mathrm{O}$ at $4^{\circ} \mathrm{C}$ for long-term storage. The inoculum was prepared from 7-day-old cultures grown at $25^{\circ} \mathrm{C}$. Erlenmeyer flasks $(125 \mathrm{~mL})$ containing $50 \mathrm{~mL}$ of minimal medium (MM) (32) were inoculated for a final spore concentration of $10^{6}$ spores $\mathrm{mL}^{-1}$ and shaken $\left(150 \mathrm{rpm} ; 25^{\circ} \mathrm{C}\right)$. Bacterial transformation was carried out using method proposed by Inoue et al. (20).

\section{Morphological characterization of $P$. expansum and $P$.griseoroseum}

Fungi were grown in specific medium to differentiate species of Penicillium, Czapek Yeast Extract Agar (CYA) and Neutral Creatine Sucrose Agar (CSN), as described by Pitt and Hocking (31). Colors of colony were recorded under bright tungsten illumination and designated according to Munsell Color Charts (23).

\section{DNA extraction and Southern blot}

Penicillium expansum and P. griseoroseum total DNA was extracted according to Specht et al. (40) and cleaved with restriction enzymes AluI, BamHI, EcoRI, HindIII and SmaI. The reactions were analyzed on $0.8 \%$ agarose gel, and then transferred to Duralon membranes (Stratagene) according to Sambrook et al. (37). The membrane was probed with the plasmid pTel13 (22) containing 225 bp DNA fragment labeled with [ $\alpha-$ $\left.{ }^{32} \mathrm{P}\right] \mathrm{d}-\mathrm{ATP}$, using "Random Primer-It II Labeling Kit" (Stratagene). Hybridization was carried out overnight at $60^{\circ} \mathrm{C}$ in standard hybridization buffer, washed twice with 2 X SSC, $0.1 \%$ SDS for $20 \mathrm{~min}$, and $1 \mathrm{X} \mathrm{SSC}, 0.1 \%$ SDS for $10 \mathrm{~min}$. Autoradiographs were taken by three-day exposure of XOMAT K film (Kodak), with an intensifying screen.

\section{PCR amplification of ribossomal DNA regions}

The ribossomal ITS1-5.8S rRNA gene-ITS2 region was amplified with primers ITS1 (5'-TCCGTAGGTGAACCTGCGG3') and ITS4 (5'-TCCTCCGCTTATTGATATGC-3') constructed for molecular phylogenetic studies (43). PCR amplification was performed in $25 \mathrm{~mL}$ reaction mixtures containing $10 \mathrm{ng}$ of genomic DNA template, $1.0 \mathrm{U}$ of Taq DNA polymerase (Promega), $40 \mathrm{pmol}$ of each primer, $10 \mathrm{mM}$ Tris- $\mathrm{HCl}(\mathrm{pH} 8,3), 50$ $\mathrm{mM} \mathrm{KCl}, 2.5 \mathrm{mM} \mathrm{MgCl} 2,0.1 \mathrm{mM}$ of each dNTP (dATP, dCTP, dGTP e dTTP). Amplification was performed in a thermocycler PCT-100 (MJ Research, Inc.) for 40 cycles, each cycle consisting of a denaturation step $\left(15 \mathrm{~s} ; 94^{\circ} \mathrm{C}\right)$, an annealing step $\left(30 \mathrm{~s} ; 35^{\circ} \mathrm{C}\right)$, and a extension step $\left(60 \mathrm{~s} ; 72^{\circ} \mathrm{C}\right)$. After the 40th cycle, a final extension step was performed $\left(60 \mathrm{~s} ; 72^{\circ} \mathrm{C}\right)$. ITS PCR products were cloned into pGEM-T Easy Vector System (Promega). This vector was used to transform E. coli DH5a and the plasmidial DNA was extracted by alkaline lysis method (37). The primers M13 forward and reverse (Promega) and "BigDye ${ }^{\mathrm{TM}}$ " kit Terminator Cycle Sequencing Ready Reaction" (Applied Biosystems) were used to sequence both strands. The ITS sequences were analysed and aligned using BLAST and CLUSTAL W software. Sequence data were deposited in the GenBank Nucleotide Database.

\section{RAPD analysis}

PCR amplification of DNA from $P$. expansum and $P$. griseoroseum was performed with 78 random primers (Operon Technologies Inc., Alameda, CA) as described by Williams et 
al. (44). Amplification products were electrophoresed in $1.5 \%$ (w/v) agarose gels immersed in TEB running buffer $(90 \mathrm{mM}$ Tris-borate, 2 mM.L.-1 EDTA, pH 8.0) and run for $4 \mathrm{~h}$ at $100 \mathrm{~V}$. The gels were stained with ethidium bromide $\left(0.5 \mu \mathrm{g} \mathrm{mL} \mathrm{m}^{-1}\right)$. The images were captured and stored using a photo documentation system (Eagle Eye II, Stratagene, La Jolla, California).

\section{RESULTS AND DISCUSSION}

The taxonomy of Penicillium has always been complex due to its great number of species (nearly 250), which have very few differences. This fact complicates researchers understanding of their ecology, diversity and consequently its exploration by industry. Classification systems of organisms are historically based on observable characteristics. The growth of isolates in appropriate culture media, enabling their most characteristic features to be recognized, is still the most common procedure used in practice. Many species classified in sub-genus Penicillium are morphologically similar, and identification using traditional morphological techniques remains difficult. Pitt $(28,30)$ and Frisvad $(17,18)$ media introduced for identification of Penicillium species provide a very useful tool to distinguishing between these difficult and closely related species. The $P$. expansum and $P$. griseoroseum strains were grown on specific medium CYA and CSN at 5, 25, and $37^{\circ} \mathrm{C}$. No growth was observed at 5 and $37^{\circ} \mathrm{C}$ for 7 days on medium CYA. At $25^{\circ} \mathrm{C}$, vigorous growth with distinctive features between $P$. expansum and $P$. griseoroseum colonies (Fig. 1) was recorded. Colonies on CYA produce 30-37 diameter green conidia, with mycelium white at the margins. $P$. expansum conidia presented light green color with radially sulcate, velutinous texture, reverse yellow. Dull green conidia, surface texture from granular to floccose, and presence of an orange brown soluble pigment, reverse pale, was observed in $P$. griseoroseum colonies. On CSN ( 2 days; $25^{\circ} \mathrm{C}$ ), it was observed differences in the diameter and coloration of colony reverses. $P$. expansum colonies produce green conidia and violet reverse. Smaller colonies with green conidia and pale yellow reverse were observed in P. griseoroseum. After incubation for 7 days on CSN, P. expansum colonies showed irregular growth, presented pale green conidia, velutinous texture, violet reverse. Dull green conidia, regular surface texture, reverse reddishviolet were observed in $P$. griseoroseum colonies. These isolates give a very strong alkaline reaction on Neutral Creatine Sucrose agar, although Pitt and Hocking (31) described an acid reaction for $P$. expansum.

Although identification by the traditional morphological criteria is very effective in large and complex Penicillium genera, the large number of existing species has created a need for alternative approaches. Molecular methods have been used to improve the understanding of the natural taxonomy of Penicillium. As telomere-associated sequences generally vary

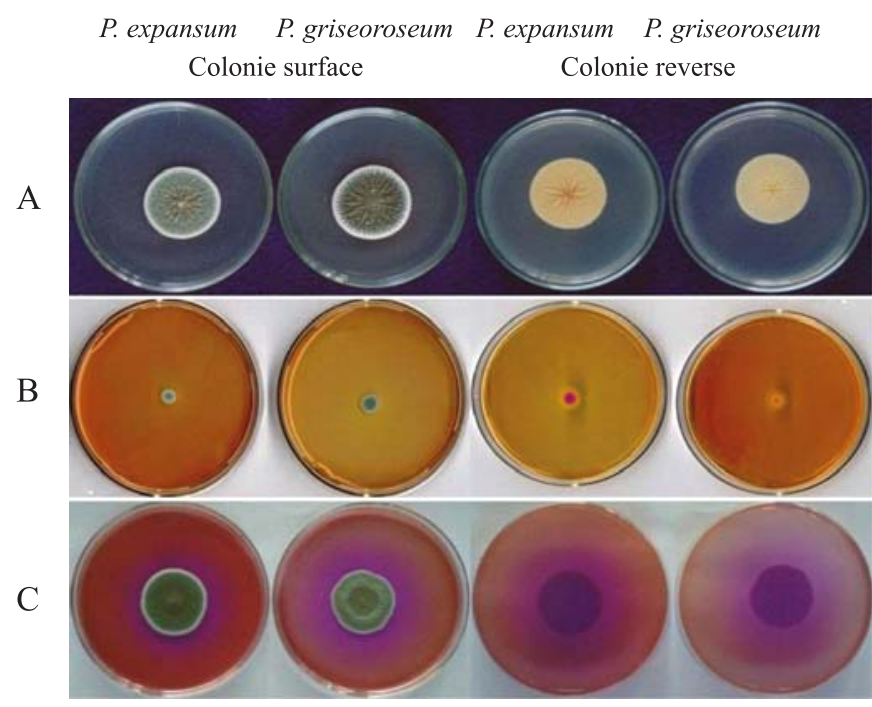

Figure 1. Morphological characterization of $P$. expansum and $P$. griseoroseum. Colonies have been grown in medium CYA for 7 days (A), CSN for 2 (B) and 7 days (C), at $25^{\circ} \mathrm{C}$.

considerably in length, complexity and species-specific sequences, the telomeric molecular marker could be an excellent tool for fingerprint and further epidemiological studies (24). Telomeres are essential for genome stability in all eukaryotes. These terminal structures serve as functional complexes that protect chromosomal ends by preventing terminal fusions and degradation (6,7). Telomere DNA has been isolated from diverse filamentous fungi and all have the same TTAGGG repeat (22). The plasmid pTel13 contain 8 repeats at one end and 3 at the other end and only $159 \mathrm{bp}$ of the $225 \mathrm{bp}$ correspond to a subtelomeric region specific from the phytopathogenic fungus Botrytis cinerea. This probe is therefore non-specific to $B$. cinerea, and it is likely that the observed signal with these other fungi is not due to the specific $B$. cinerea sequence, but to the TTAGGG repeats present in pTel13 making it a convenient tool for probing telomeric sequences (22). In the case of Beauveria bassiana, an entomopathogenic fungus, the use of pTel13 for fingerprint allowed to suggest that the observed polymorphism corresponds to the insect-host and not to the geographic origins of isolates (42). The presence of TTAGGG repeats and organization of the subtelomeric region of cromossomes of $P$. expansum and $P$. griseoroseum was checked using pTel13 as probe (Fig. 2). This probe was hybridized to genomic DNA from P.expansum and P. griseoroseum, and cut with five different restriction enzymes. The Southern blot results show the presence of TTAGGG repeats of the subtelomeric region of cromossomes of these fungi and the polymorphism in the organization of the region, indicating that the genomes of these two species are not identical. The analysis showed that the chromosome minimal numbers estimated were three. 


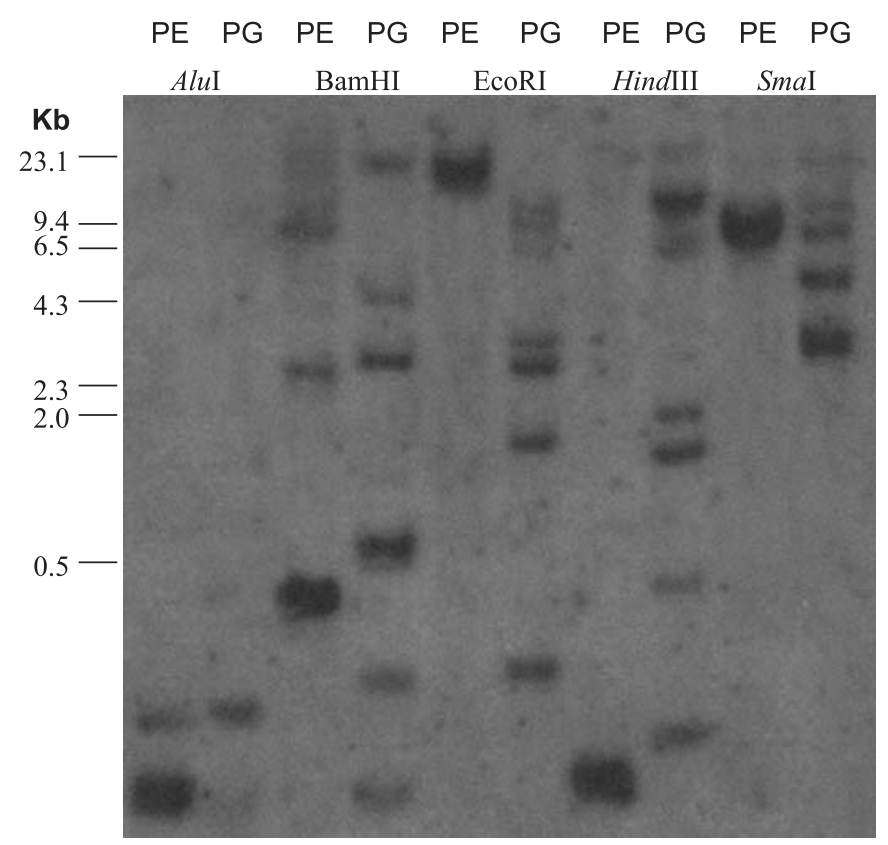

Figure 2. Southern blot analysis of digest DNA from $P$. expansum (PE) and P. griseoroseum (PG). The blot was probe with radiolabelled pTel13. The sizes of DNA fragments are indicated in kilobases on the left.

The genetic diversity of some Penicillium species was also studied by random amplified polymorphic DNA $(15,39)$. RAPD analyses were performed for $P$. expansum and $P$. griseoroseum using 78 single primers of arbitrary sequences. These species presented differences in band patterns using only 8 primers, since $54 \%$ of the amplified fragments were polymorphic (Fig. 3). In spite of the small number of amplified polymorphic fragments between $P$. expansum and $P$. griseoroseum, those results indicate differences in the genome of these two species. It was therefore expected that very distinct patterns would be observed when used to study different species, but identical patterns from RAPD analysis of different Penicillium spp. with 21 primers was reported by Dupond et al. (14). Molecular characterization based on the RAPD markers among 10 Penicillium species was reported by Pereira et al. (25). High polymorphism among the species $P$. roqueforti, $P$. oxalicum, $P$. griseofulvum, $P$. brevicompactum, $P$. camembertii and $P$. charlesii was demonstrated by the amplifications (25). The species $P$. purpurogenum and $P$. crustossum did not present polymorphism nor did $P$. expansum and $P$. griseoroseum. In our study, a higher polymorphism was detected among $P$. expansum and $P$. griseoroseum by RAPD analysis than reported by Pereira et al. (25), probably due to the different number of primers utilized in both studies. RAPD analyses were performed for $P$. expansum and $P$. griseoroseum using 78 single primers of arbitrary sequences, despite the fact that in Pereira et al. (25) PCR

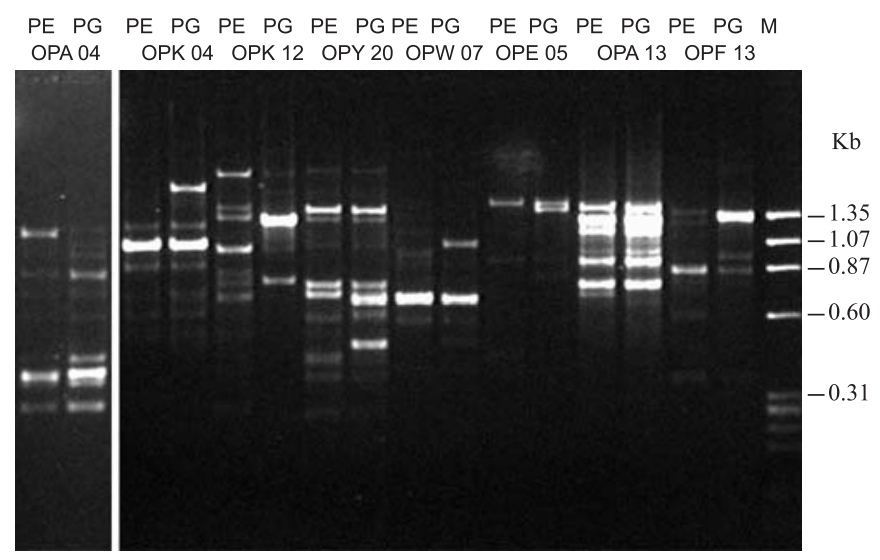

Figure 3. Gel eletrophoresis of the RAPD amplified products from $P$. expansum (PE) and P. griseoroseum (PG) obtained with different primers. Column $\mathrm{M}$ shows the band pattern for the fragment size marker ( $\phi$ X174 digested with HaeIII).

amplifications was performed with 18 random primers only, so the polymorphism between species in the subgenus Penicillium was probably underestimated. Our results emphasize the need to use the largest possible number of random primers to generate greater polymorphism in the high homogeneous subgenera Penicillium.

The rDNA ITS region was obtained for $P$. expansum and $P$. griseoroseum using the specific primers ITS1 and ITS4. The monomorphic fragment of $600 \mathrm{bp}$ was amplified for $P$. expansum and nucleotide sequence deposited into GenBank with accession number AY425984. For P. griseoroseum, the size of the amplified ITS region was of $594 \mathrm{bp}$ and nucleotide sequence deposited into GenBank with accession number AY425983. The size of the amplified ITS region is similar to that reported for other Penicillium species $(8,14,39)$. ITS sequence of $P$. expansum and $P$. griseoroseum were aligned with ITS sequences of others Penicillium species (Fig. 4). The multiple sequence alignment showed high homology of nucleotide among all species. No ITS sequence variation was detected between $P$. expansum and $P$. griseoroseum excepting the additional six initial nucleotides.

Our results show that the comparison of nucleotide sequence ITS region between species of the genus Penicillium does not reveal a satisfactory discrimination because of the very low degree of ITS variability. On the other hand, the organization of the subtelomeric region and RAPD allows the analysis of the entire genome and gives a discriminatory level even between species indicating that the genomes of these two species are not identical. Despite the fact that Pitt (30) introduced an approach based on gross physiology under standardized conditions, these procedures are not yet effective for all species of the genus creating a need for alternative approaches (29). 
P. griseoroselm VIC

P. italicus

p. expansuan VIC

P. crustosim

P. cominiane

P. camenberti

P. chrysogerum

p. expansuan $X 0$

v. expansun UB

P. expansun wi
P. rocueforti

P. griseoroselm VIC

p. italicus

P. expansuan VIC

P. crustosim

p. ccouneme

p. cominime

P. camenberti

p. expansuan $\mathrm{XO}$

P. expansua UB

p. rocuefort

griseoraseim

p. italicus

P. expansuin vIC

P. crustosum

P. cominume

P. camenberti

p. chrysogerain

P. expansun $\mathrm{XO}$

P. expansuan WB

p. rocueforti

p. griseoraseim VIC

p. italicun

P. expansuin VIC

P. crus tosim

P. coniniase

P. camenberti

D. chrysogerim

p. expansum $\mathrm{X0}$

P. expansuin XO

p. expansua W
P. rocueforti

TGGTGAACC TGCGGAAGGATCATT ACC GAGTGAGGGCCCTC TGGGTCCAACCTCCCACCCGT GTT TAT TTT ACCTTGTTGCTTCGGCGGGC

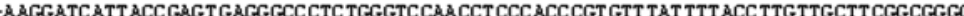

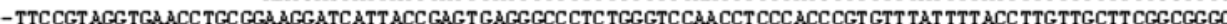
G GGAAGTAAAAGTCG TAACAAGGT TTCCGT AGG TGAACC TCCGGAAGGATCATT ACC GAGT GAGGGCCCTC TGGGTCCAACCTCCCACC CGT GTT TAT TTT ACC TTG TTGCTT CGGCGGCC GGAAG TAAAAGTCG TAACAAGGT TTCCGT AGGTGAACC TGCGGAAGGATCATT ACCGAGT GAGGGCCCTC TGGGTCCAACCTCCC ACCCGT GTT TAT TTT ACC TTGTTGCTTCGGCGGGC 作 -TTTCCGT ACGTGA ACC TGCGGAACGATCATT ACCGAGTGACGGCCCTTTGGGTCCAACCTCCC ACCCGT GTTT TATTT-ACCTCGTTGCTTCGGCGGGC ACAAGGTTTCGT AGGTGAACC TGCGGAAGGATCATT ACCGAGTGAGGGCCCTC TGGGTCCAACCTCCCACCCGT GTT TAT TTTACC TCGTTGCTTCGGCGGGC GGAAGTAAAAGTCGTAACAAGGT TTCCGT AGGTGAACC TCCGGAAGGATCATT ACCGAGT GAGGGCCCTC TGGGTCCAACCTCCCACCCGT GTT TAT TTT ACC TCGTTGCTTCGGCGGGC $* * * * * * * * * * * * * * * * * * * * * * * * * * * * * * * * * * * * * * * * * * * * * * * * * * * * * * * * * * *) * * * * * * * * * * * *)$ CСGCC TTAACT GGC CGC CGGGGGGCT TACGCC CCCGGGCCCGCGCCC GCCGAAGACACCCT CGAACT CTGTCT GAAGAT TGAAGT CTGAGT GAAAAT ATAAAT TAT TTAAAACTT TCAAC CCGCC TTAACT GCCCGCCGGGGGGCT TACGCCCCCGGGCCCGCGCCCGCCGAAGACACCCT CGAACTCTGTCT GAAGAT TGAAGT CTGAGT GAAAAT ATAAAT TAT TTAAAACTT TCAAC CCGCC TTAACT GGCCGCCGGGGGCCT TACGCCCCCGGGCCCGCGCCC GCCGAAGACACCCT CGAACTCTGTCT GAAGAT TGAAGT CTGAGT GAAAAT ATAAAT TAT TTAAAACTT TCA AC

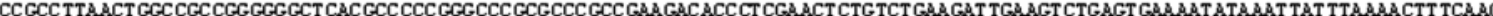
CCGCC TTAACT GCCCGCCGGGGGCCT CACGCCCCCGGGCCCGCGCCC CCCGAAGACACCCT CGAACTCTGTCT GAAGAT TGAAGTCTGAGT GAAAAT ATAAAT TAT TTAAAACTT TCAAC CCGCC TTAACT GGCCGCCGGGGGGCT TACGCCCCCGGGCCCGCGCCCGCCGAAGACACCCT CGAACTCTGTCT GAAGAT TGT AGTCTGAGT GAAAAT ATAAAT TAT TTAAAACTT TCAAC

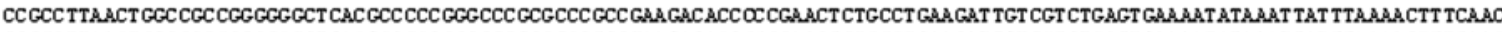
CCGCC TTAACT GCCCGC CGGGGGCCT CACGCCCCCGCGCCCGCGCCCGCCGAAGACACCOCCGAACTCTGCCT GAAGAT TGT CGT CTGAGT GAAAAT ATAAAT TAT TTAAAACTT TCAAC CCGCC TTAACT GGCCGCCGGGGGGTT TACACCCCCGGGCCCGCGCCCGCCGAAGACACCC-CGAACTCTGTCT GAAGAATGCAGT CTGAGAACAAAT ATAAAT TAT TTAAAACTT TCAAC

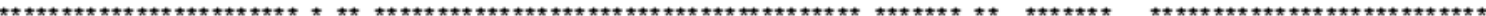
AACGCATCTCT TGCTTCCCGCATCGA TGAAGAACGCAGCGAAATGCGATACGT AATGTGAGGCGCATGCC TGT CCGACCGTCATTCCTCCCCTCAACCCCGCC TTGTGT GTT CCCCCCCC AACGGATC TCT TGGTTCCGGCATCGA TGAAGAACGCAGCGAAAT GCGATACGT AAT GTGAGGGGCAT GCC TGT CCGAGCGTCATT GCT GCCCTCAAGCCCGCC TTGTGT GTT GGGCCCCC AACGGATC TCT TGGTTCCGGCATCGA TGAAGAACGCAGCGAAAT GCGATACGT AAT GTGAGGGGCAT GCC TGT CCGACCGTCATT GCT GCCCTCAAGCCCGCC TTGTGT GTT GCGCCC CC AACGGATC TCT TGGTTCCGGCATCGA TGAAGAACGCAGCGAAAT GCGATACGT AAT GTGAGGGGCAT GCC TGT CCGACCGTCATT GCT GCCCTC AAGCCCGGC TTGTGT GTT GGGCCCC AACGGATC TCT TGGTTCCGGCAT CGA TGAAGAACGCAGCGAAAT GCGATACGT AAT GTGAGGGGCAT GCC TGT CCGAGCGTCATT GCT GCCCTCAAGCCCGCCTTGTGT GTT GGGCCCC AACGGATC TCT TGGTTCCGGCATCGA TGAAGAACGCAGCGAAATGCGATACGT AATGTGAGGGGCATGCC TGTCCGACCGTCATT TCT GCCCTCAAGCACGCC TTGTGTGTTCECCCCC AACGGATC TCT TGGTTCCGGCATCGA TGAAGAACGCAGCGAAAT GCGATACGT AAT GTGAGGGGCAT GCC TGT CCGAGCGTCATT GCT GCCCTCAAGCCCGEC TTGTGT GTT GGGCCCCC AACGGATC TCT TGGTTCCGGCATCGA TGAAGAACGCAGCGAAAT GCGATACGT AAT GTGAGGGGCATGCC TGT CCGAGCGTCATT GCT GCCCTCAAGCCCGGC TTGTGT GTT GGGCCC CC AACGGATC TCT TGGTTCCGGCAT CGA TGAAGAACGCAGCGAAAT GCGATACGT AAT GTGAGGGGCAT GCC TGT CCGAGCGTCATT GCT GCCCTCAAGCCCGGC TTG TGT GTT GGGTCT CC

GCGTA TGGGCCTTT GTCACCCGC TCT GTAGCCCCGGCCGCCGCT TGCCGA TCAACCCAAAT TTT TATCCAGGT TGACCTCGGATCACGTAGGGA TACCCGCTGAACTTAACC ATA TCAAT

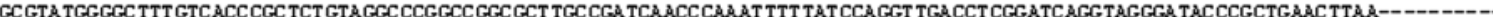
GCGTATGGGGCTTT GTCACCCGC TCT GTAGCCCCGGCCGCCGCT TGCCGATCAACCCAAAT TTT TATCCAGGT TGACCTCGGATCAGGTAGGGA TACCCGCTGAAC TTAACCATATCAAT GCGTA TGGGGCTTT GTCACCCGC TCT GTAGCCCCGGCCG-CGCT TGCCGA TCAACCCAAAT TTT TATCCAGGT TGACCTCGGATCAGGTAGGGA TACCCGCTGAAC TTAAGCATA TCAAT GCGTA TGGGCC TTT GTCACCCGC TCT GTAGGCCCGGCCGCCGCT TGCCGA TCAACCCAAAT TTT TATCCAGGT TGACCT CGGATCAGGTAGGGA TACCCGCTGAAC TTAAGCATATCAAT GCGTATGGGCC TTT GTCACCCGC TCT GTAGCCCCGGCCGCCGCT TCCCGA TCAACC CAAAT TTT TATCCAGGT TGACCT CGGATCAGGTAGGGA TACCCGCTGAAC TTAAGCATA TCAA GCGTA TGGGCC TTTGTC ACCCGC TCT GTAGCCCCGGCCGCCGCT TGCCGA TCAACCCAAAT TTT TATCCAGGT TGACCTCGGATC ACGTAGGGA TACCCGCTGAAC TTAACCATATCAAT GCGTA TGGGGCTTT GTCACCCGC TCT GTAGCCCCGGCCGCCGCT TGCCGA TCAACCCAAAT TTT TATCCAGGT TGACCT CGGATCAGGTAGGGA TACCCGCTGAACTT------------GCGTATGGGCC TTT GTCACCCCC TCT GTAGCCCCGGCCGCCGCT TGCCGA TCAACCCAAAT TTT TATCCAGGT TGACCTCGGATCAGGTAGGGA TACCCGCTGAAC TTAAGCATATCAAT GCGTA TGGGCCTTT GTCACCCGC TCT GTAGCCCCGGCCGCCGCT TGCCGA TCAACCCAAAT TTT TATCCAGGT TGACCTCGGATCAGGTAGGGA TACCCGCTGAAC TTAAGCATATCAAT

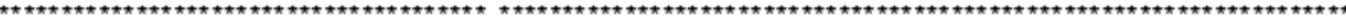

Figure 4. Multiple alignment of the ITS region of P. expansum (this study), P. griseoroseum (this study), P. italicum (AJ250548), P. crustosum (X82361), P. commune (AJ004813), P. camembertii (AJ004814), P. chrysogenum (AF455490), P. expansum (XO) (AJ005676), P. expansum isolate wb342 (WB) (AF455466) and P. roqueforti (AJ005677). GenBank accession numbers in parentheses. Asterisks indicate identical nucleotides.

The polymorphism observed in the organization of the subtelomeric region in the genome of two Penicillium species within the high homogeneous Penicillium subgenera is for the first time reported and perhaps can be employed in future phylogenetics studies for the species belonging to this fungi subgenus. The integration of different methods and techniques should lead to the identification of useful markers for the standardization of global taxonomical studies of Penicillium species.

\section{ACKNOWLEDGMENTS}

The authors thank the Brazilian agencies CNPq (Conselho Nacional de Desenvolvimento Científico e Tecnológico), MCT/ CAPES (Coordenação de Aperfeiçoamento de Pessoal de Nível Superior) and FAPEMIG (Fundação de Amparo à Pesquisa do Estado de Minas Gerais) for financial support.

\section{RESUMO}

\section{Diferenciação morfológica e molecular de fungos produtores de pectinases Penicillium expansum e Penicillium griseoroseum}

Penicillium expansum $P$. griseoroseum foram caracterizados morfológica e molecularmente. Variações na morfologia das colônias e coloração dos conídeos foram observadas entre os isolados. A caracterização molecular foi baseada em marcadores RAPD, sequenciamento da região do espaçador interno transcrito do DNA ribossomal e "fingerprinting" telomérico. Foi usado um total de 78 primers RAPD, sendo que 8 apresentaram $54 \%$ de fragmentos de DNA polimórficos. Os produtos da amplificação da região ITS de $P$. expansum e $P$. griseoroseum foram de 600 e $594 \mathrm{pb}$, respectivamente. Não foi detectada nenhuma variação na sequiência de nucleotídeos dessa região, comparando-se $P$. 
expansum e $P$. griseoroseum, exceto em relação aos seis nucleotídeos iniciais adicionais. Observou-se a ocorrência de polimorfismo na organização da região subtelomérica no genoma destes fungos e estimou-se um número mínimo de três cromossomos para estas espécies. Este é o primeiro trabalho que descreve a existência de polimorfismo na organização da região subtelomérica do genoma de espécies de fungos pertencentes ao gênero Penicillium, altamente homogêneo, indicando uma possível utilização da abordagem empregada neste estudo para pesquisas filogenéticas futuras.

Palavras-chave: DNA ribossômico, Espaçador Transcrito Interno, Região Subtelomérica, Penicillium spp.

\section{REFERENCES}

1. Baracat-Pereira, M.C.; Coelho, J.L.C.; Minussi, R.C.; Chaves-Alves, V.M.; Brandão, R.L.; Silva, D.O. (1999). Cyclic AMP and low molecular weight effector(s) present in yeast extract are involved in pectin lyase production by Penicillium griseoroseum cultured on sucrose. Appl. Biochem. Biotechnol., 76, 129-141.

2. Baracat-Pereira, M.C.; Coelho, J.L.C.; Silva, D.O. (1994). Production of pectin lyase by Penicillium griseoroseum cultured on sucrose and yeast extract for degumming of natural fibres. Lett. Appl. Microbiol., 18, 127-129.

3. Baracat-Pereira, M.C.; Minussi, R.C.; Coelho, J.L.C.; Silva, D.O. (1997). Tea extract as an inexpensive inducer of pectin lyase in Penicillium griseoroseum cultured on sucrose. J. Ind. Microbiol., 18, 308-311.

4. Baracat-Pereira, M.C.; Valentim, C.; Muchovej, J.J.; Silva, D.O. (1989). Selection of pectinolytic fungi for degumming of natural fibers. Biotechnol. Lett., 11, 899-902.

5. Bazzolli, D.M.S.; Ribon, A.B.O.; Queiroz, M.V.; Araújo, E.F. (2006). Molecular characterization and expression profile of pectin lyaseencoding genes from Penicillium griseoroseum. Can. F. Microbiol., 52, 1070-1077.

6. Blackburn, E.H. (2001). Switching and signalling at the telomeres. Cell, 106, 661-673.

7. Blackburn, E.H. (2000). Telomere states and cell fates. Nature, 408, 53-56.

8. Boysen, M.; Skouboe, P.; Frisvad, J.; Rossen, L. (1996). Reclassification of the Penicillium roqueforti group into three species on the basis of molecular genetic and biochemical profiles. Mycrobiology, 142, 541-549.

9. Brito, A.R.T. (1998) Isolamento e caracterização de mutantes de Penicillium griseoroseum. Viçosa, Brasil, 74p. (MSc Dissertation. Departamento de Microbiologia, UFV).

10. Brumano, M.H.N.; Coelho, J.L.C.; Araújo, E.F.; Silva, D.O. (1993b). Pectin lyase activity of Penicillium griseoroseum related to degumming of ramie. Rev. Microbiol., 24, 175-178.

11. Brumano, M.H.N.; Coelho, J.L.C.; Araújo, E.F.; Silva, D.O. (1993a). Production of pectin lyase by Penicillium griseoroseum as a function of the inoculum and culture conditions. World J. Microbiol. Biotechnol., 9, 225-228.

12. Cardoso, P.G. (2004). Organização do gene de pectina liase em Penicillium expansum e obtenção de linhagens recombinantes de Penicillium griseoroseum com alta produção de pectina liase. Viçosa, Brasil, 121p. (Ph.D. Dissertation. Departamento de Microbiologia, UFV).

13. Dias, E.S.; Araújo, E.F.; Guimarães, W.V.; Coelho, J.L.C.; Silva, D.O. (1997). Production and regeneration of Penicillium expansum and Penicillium griseoroseum protoplasts. Braz. J. Microbiol., 28, 116-120.

14. Dupont, J.; Magnin, S.; Marti, A.; Brousse, M. (1999). Molecular tools for identification of Penicillium start cultures used in the food industry. J. Food Microbiol., 49, 109-118.

15. Durand, N.; Reymond, P.; Févre, M. (1993). Randomly amplified polymorphic DNAs assess recombination following and induced parassexual cycle in Penicillium roqueforti. Curr. Genet., 24, 417420 .

16. Fernandes-Salomão, T.M.; Amorim, A.C.R.; Chaves-Alves, V.M.; Coelho, J.L.C.; Silva, D.O.; Araújo, E.F. (1996). Isolation of pectinases hyperproducing mutants of Penicillium expansum. Braz. J. Microbiol., 27, 15-18.

17. Frisvad, J.C. (1985). Creatine sucrose agar, a diferential medium for mycotoxin producing terveticillate Penicillium species. Lett. Appl. Microbiol., 1, 109-113.

18. Frisvad, J.C. (1981). Physiological criteria and mycotoxin production as aids in identification of common asymmetric penicillia. Appl. Env. Microbiol., 41, 568-579.

19. Grassin, C.; Fauquembergue, P. (1996). Fruit juices. In: Godfrey, T., West, S. (eds). Industrial Enzymology. MacMillan, London, p.225264.

20. Inoue H.; Nojima, H.; Okayama, H. (1990). High efficiency transformation of Escherichia coli with plasmids. Gene, 96, 2328.

21. Lana, T.G. (1999). Isolamento e caracterização de linhagens diplóides e recombinantes em Penicillium expansum. Viçosa, Brasil, 55p. (MSc Dissertation. Departamento de Microbiologia, UFV).

22. Levis, C.; Giraud, T.; Dutertre, M.; Fortini, D.; Brygoo, Y. (1997). Telomeric DNA of Botrytis cinerea: a useful tool for strain identification. FEMS Microbiol. Lett., 157, 267-272.

23. Munsell soil color charts. (1990). Macbeth Division of Kollmorgen Instruments, Corporation, Baltimore.

24. Neplechová, K.; Sýkorová, E.; Fajkus, J. (2005). Comparison of different kinds of probes used for analysis of variant telomeric sequences. Biophysical Chemistry, 117, 225-231.

25. Pereira, J.F.; Queiroz, V.M.; Gomes, E.A.; Muro-Abad, J.I.; Araújo, E.F. (2002). Molecular characterization and evaluation of pectinase and celulase production of Penicillium spp. Biotechnol. Lett., 24, 831-838.

26. Piccoli-Valle, R.H.; Passos, F.J.V.; Brandi, I.V.; Peternelli, L.A.; Silva, D.O. (2003). Influence of different mixing and aeration and regimens on pectin lyase production by Penicillium griseoroseum. Process Biochem., 38, 849-854.

27. Piccoli-Valle, R.H.; Passos, F.M.L.; Passos, F. J.V.; Silva, D.O. (2001). Production of pectin lyase by Penicillium griseoroseum in bioreactors in the absence of inducer. Braz. J. Microbiol., 32, 135-140.

28. Pitt, J.I. (1995). Phylogeny in the genus Penicillium: a morphologist's perspective. Can. J. Bot., 73, 768-777.

29. Pitt, J.I. (1993). Speciation and evolution in Penicillium and related genera. In: Reynolds, D.R.; Taylor, W. (eds) The fungal holomorph: mitotic, meiotic and pleomorphic speciation in fungal systematics. Wallingford, CAB International, p.113-117.

30. Pitt, J.I. (1980). The Genus Penicillium and its teleomorphic states Eupenicillium and Talaromyces. Academic Press, London, United Kingdom.

31. Pitt, J.I.; Hocking, A.D. (1997) Fungi and Food Spoilage. Maryland, Aspen Publishers Inc., Maryland.

32. Pontecorvo, G.; Roper, J.A.; Hemmons, L.M.; MacDonald, K.D.; Bufton, A.W.J. (1953). The genetics of Aspergillus nidulans. Adv. Genet., 5, 141-238.

33. Queiroz, M.V.; Barros, A.O.; Barros, E.G.; Guimarães, W.V.; Araújo, E.F. (1998). Transformation of Penicillium griseoroseum nitrate reductase mutant with the nia gene from Fusarium oxysporum. Can. J. Microbiol., 44, 487-489. 
34. Ribon, A.O.B.; Coelho, J.L.C.; Barros, E.G.; Araújo, E.F. (1999). Cloning and characterization of a gene encoding the endopolygalacturonase of Penicillium griseoroseum. Biotechnol. Lett., 21, 395-399.

35. Ribon, A.O.B.; Queiroz, M.V.; Araújo, E.F. (2002a). Structural organization of polygalacturonase-encoding genes from Penicillium griseoroseum. Genet. Mol. Biol., 25, 489-493.

36. Ribon, A.O.B.; Queiroz, M.V.; Coelho, J.L.C.; Araújo, E.F. (2002b) Differential expression of polygalacturonase-encoding genes from Penicillium griseoroseum in different carbon sources. J. Ind. Microbiol. Biotechnol., 29, 145-148.

37. Sambrook, J.; Fritsch, E.F.; Maniatis, T.A. (1989). Molecular cloning: a laboratory manual. Cold Spring Harbor Press, New York.

38. Santos, J.K. (1999). Fusão de protoplastos em Penicillium griseoroseum visando o melhoramento na produção de pectinases. Viçosa, Brasil, 65p. (Monografia de graduação, Universidade Federal de Viçosa).

39. Sequera, J.; Marneisse, R.; Valla, G.; Normand, P.; Capellano, A.; Moiroud, A. (1997). Taxonomic position and intraspecific variability of the nodule forming Penicillium nodositatum inferred from RFLP analysis of the ribossomal intergenic spacer and random amplified polymorphic DNA. Mycol. Res., 101, 465-472.

40. Specht, C.A.; DiRusso, C.C.; Novotny, C.P.; Ullrich, R.C. (1982). A method for extracting high-molecular-weight deoxyribonucleic acid from fungi. Analyt. Biochem., 119, 158-163.

41. Varavallo, M.A.; Marisa Queiroz, M.V.; Lana, T.G.; Brito A.T.R.; Gonçalves, D.B.; Araújo, E.F. (2007). Isolation of recombinant strains with enhanced pectinase production by protoplast fusion between Penicillium expansum and Penicillium griseoroseum. Braz. J. Microbiol., 38, 1-6.

42. Viaud, M.; Couteaudier, Y.; Levis, C.; Riba, G. (1996). Genome organization in Beauveria bassianna: electrophoretic karyotype, gene mapping and telomeric fingerprint. Fungal Genet. Biol., 20, 175-183.

43. White, T.J.; Bruns, T.; Lee, S.; Taylor, J. (1990). Amplification and direct sequencing of fungal ribosomal RNA genes for phylogenetics. In: Innis, M.A.; Gelfand, D.H.; Sninsky, J.J.; White, T.J. (eds) PCR Protocols: A Guide to Methods and Applications. Academic Press, San Diego, p.315-322.

44. Williams, J.G.; Kubelik, A.R.; Livak, K.J.; Rafalski, J.A.; Tingey, S.V. (1990). DNA polymorphisms amplified by arbitrary primers are useful as genetics markers. Nucl. Acids Res., 18, 6531-6535. 